\title{
Influence of Thermodynamic Phenomena at the Optimum Cutting Parameters when Grin- ding
}

Karel Kocman

Institute of Production Engineering, Fakulty of Technology Tomas Bata University in Zlin, E-mail: profkocman@seznam.cz

In particular, the quantitative and qualitative results of the technological process are in most cases determined by the level of finishing operations, which include in particular grinding. It is characterized by high precision, the accuracy of geometric shape and generally very good quality surface. One of the factors to achieve the desired quality of finished surfaces, in particular, knowledge of the effect of temperature of the contact surface of the grinding wheel and the ground. In the article is the methodology of the quantification of the impact of cutting parameters on the temperature of the grinding. Another requirement is the right choice of other cutting parameters, to guarantee the achievement of the required accuracy dimensions and shape, increase performance and decrease the temperature of the contact of the cut surface with a grinding wheel.

The result is the desired surface integrity and the exclusion of undesirable residual stress in the lustre of the surface. In the case of the quantification of the individual characteristics of the grinding on the optimization of the grinding process, it is possible to achieve this objective

Keywords: energy characteristics of the grinding, cutting, grinding the surface integrity parameters, residual voltage, quantification of heat and temperature

\section{References}

[1] ABELlan, J. V., ROMERO, F., SILLER, H. R. et al. (2008). Adaptive Control Optimization of Cutting Parameters for High Quality Machining Operations Based on Neural Networks and Search Algorithms. Advances in Robotics, Automation and Control, Jesus Aramburo and Antonio Ramirez Trevino (Ed.), In Tech, 2008. 472 pp., ISBN 978-953-7619-16-9.

[2] BOUZAKIS, K. D., PARASKEVOPOUlOU, R., GIANNOPOULOS, G. (2008). Multi-objective Optimization of Cutting Conditions in Milling Using Genetic Algorithms. In Proceedings of 3rd International Conference on Manufacturing Engineering. Greece. 2008. p.763-773.

[3] GRZINCIC, G., DJURDJEVIC, M., DIRNBERGER, F. (2013). Using of Thermal Analysis in the Industrial Practice-Consumption Reduction of Grain-Refinement Master Alloy and Optimization of Computer Simulation Results. Manufacturing Technology. March 2013, XIII, pp 39-43, ISSN 1213-2489

[4] HOLESOVSKY, F., NOVAK, M. (2010). Influence of grinding on machine parts with desing notches, Manufacturing Technolgy, IX, UJEP, Ústí n. Labem, 2010, p. 40-46, ISBN 978-80-7414-325-0.

[5] HOLEŠOVSKÝ, F., NOVÁK, M. (2009). Influence of grinding on machine parts with design notches. Manufacturing Technology. December 2009, IX, pp 40-46, ISSN 1213248-9

[6] KOCMAN, K. (2010). Analysis of development grinding wheels on the basis of microcrystalline corundum. $M a-$ nufacturing Technology, Vol. X, No. 10, p. 2-10, 2010, ISBN 978-80-7414-325-0

[7] KOCMAN, K. (2011). Technologické procesy obrábění. CERM s.r.o. Brno, leden 2011, 330 s., ISBN 978-807204-722-2

[8] KOCMAN, K. (2011). Aplication of magnetic correlation analysis on the choice and corretion of catting parameters for automated manufacturing systems. In. Manufacturing Technology, vol. XI, s. 28 - 32, December 2011, ISBN 978-80-7414-415-8

[9] MADL, J., RAZEK, V., KOUTNÝ, V., KAFKA, J. (2009). Surface Integrity in Notches Machining. Manufacturing Technology. June 2013, XIII, pp 188-193, ISSN 1213-2489

[10] MATSUBARA, A., IBARAKI, S. Monitoring and Control of Cutting Forces in Machining Processes: A Review. International Journal of Automation Technology, Kyoto, Japan, 2009. Vol. 3, No. 4, s. 445-456. ISSN $1883-8022$

[11] NOVAK, M. (2012). Surfaces with high precision of roughness after grinding. Manufacturing Technology. June 2012, XII, pp 66-70, ISSN 1213-2489

[12] NOVÁK, M. (2011). Sutface quality of hardened steels after grinding. In. Manufacturing Technology, vol. 11, s. 55 - 59, December 2011, ISBN 978-80-7414-415-8

[13] WANG, J., KURIYAGAWA, T. et. al. (2002). Optimization of Cutting Conditions for Single Pass Turning Operations Using a Deterministic Approach. International Journal of Machine Tools and Manufacture, Australia. 2002. Vol. 42, s. 1023-1033. ISSN: 0890-6955 